\title{
Existentialist Perspective: A Study of Taslima Nasrin's Novel French Lover
}

\section{Savita Yadav}

Assistant Professor

Satyawati College

University of Delhi

Delhi, India

yadavrahul3578@gmail.com

\section{Abstract}

Taslima Nasrin is a liberal humanist writer who struggles for freedom and continues to stand by people who face injustice in her writings. French Lover is the story of an Indian woman who in a traditional cover-up of patriarchy is submissive, conventional, and oppressive. The novel is a portrait of a woman who efforts to subvert the patriarchal traditions and come out from the shackles of stereotypical beliefs and conventionality. Nila, the protagonist, meanders her way in real life where she breaks and goes away from the mismatched marriage and rejects the experience offered by Benoir. Nila being a strong character retains her individuality against the destructive forces that challenged her existence. She faces an existential crisis when she detaches herself from her family, her husband, and her French lover. She undergoes the subsequent trauma and her successful exit from all the hurdles makes her realize that she has an existence of her own that is distinct from all others and She is free to choose and exist authentically. Danielle, the other character subjugated by her near and dear in her very early age, disowned her relations and denied conventionality where she lives via her way. 
Taslima Nasrin was born (1962) and brought up by Rajab Ali and Idul Ara in a small town, Mymensingh, Bangladesh. She started writing poetry at an early age of thirteen and further began writing columns in the daily newspapers and weekly magazines. After completing graduation in medical science (MBBS) from Dhaka Medical College, she turned to continuous writing. Now she has published around 35 books of poetry, essay collections, short stories, novels, and autobiographical works. Her published novels are Lajja (1994), French Lover (2002). Shodh (2003), and Homecoming published initially under the name of Phera (2005). Her literary work was first acknowledged in 1992 when she was received prestigious Anand Puraskar awarded by the Anand Bazar Patrika of Kolkata. She awarded with twenty-nine international awards, the latest among them is the Simone de Beauvoir Feminist Award for the year 2008, and Ingemar Hedenious Award 2014.

Taslima Nasrin being a rebel, reformer, lover of freedom and liberation distrusts superstition and spiritualism and attacks them whenever she gets an opportunity to do it. She is a popularly acclaimed writer as her writings recognized throughout the world. Her appeal cuts across the boundaries of race, region, culture, and religion. She denied flatly to go with and absorbed into an orthodox, conventional system of patriarchy, where she says: "I do not believe in bowing my head before anyone or anything" (Sawhney). Communal riots broke out in Bangladesh at the demolition of Babri Masjid in Ayodhya on 6 December 1992. The harrowing scenes traumatized Taslima Nasrin so vehemently that she gave expression to her shock and anguish in her novel Lajja. A fatwa (religious edict) issued against her life. The danger to the presence of a liberal writer attracted the attention of liberals all over the world. Since then she has been living away from his native land Bangladesh in different countries like India, France, Sweden and other parts of Europe.

Nasrin is undoubtedly a feminist rebellion, a critic of irrationality and a secular humanist writer, but with a difference. Saiyeda Khatun gives the pivotal importance to 
Taslima's work that reveals: "the heroine's ability to reclaim the power over her body, tearing apart the ethical cover-up of the subordinating practices of Bangladeshi patriarchy" (8). Nasrin's writing displays a dissociation of womanhood from the ideal of ethical motherhood or self-sacrifice. She flatly criticizes religion, traditions, and oppressive cultural customs which discriminate against women. She rebels against social norms and conventions. Rebellious attitude of Nasrin asserts her link to the awareness of those minimal attributes of life-related to women those to be respected and cannot be repealed under any conditions. Rebellion is thus a significant step towards the liberation of the self. Subjugated women in male-dominated society use this tool to attain and realize their sense of dignity, autonomy, and existence.

Taslima Nasrin's own experience as a woman in a Muslim society is the central thread which runs through her writings. Her characters are in constant effort to execute their potential in search of their real self by understanding and breaking the barriers of 'the endless monotony' of domestic chores, 'the unrelenting tyranny' of customs and traditions, the bastions of male learning, and above all, an inner journey into the dilemmas, pulls and pressures of an emotional world, in an attempt to make a strong presence of the self in the social and intellectual world.

A.K Tiwari's work "The Pen that defies the Sword: Taslima Nasreen's All about Women" shows that although there is political freedom in Bangladesh, yet women are oppressed and depressed under the influence of religious and patriarchal traditions. Women's rights have violated continuously, and impoverished of their rights under the male-dominated structure.

Shalini R.Sinha, in her article "Taslima Nasrin's French Lover- A flawed Journey Towards Self-Discovery," reveals that Nila, the protagonist of French Lover is ostensibly on a journey to discover her own identity. However, the journey leaves desired outcome as the 
heroine meanders her way in and out of all situations such as a failed affair, an indifferent marriage, a lesbian relationship, and finally, sexual satisfaction.

Meenakshi's study of "Various Manifestations of Quest for Identity in Taslima Nasreen's Writings: A study of Lajja and French Lover" indicates a theme of the quest for identity, in these two novels, as a significant concern of the novelist and provides a better understanding of various aspects of her philosophy. In French Lover through her protagonist, Nilanjana (Nila) Nasrin explores the gender generated identity-crisis in the man-woman relationship.

P. Kannan's "'Rejection of Man' in Taslima Nasrin's French Lover", presents a subjugation of women in male-dominated religious and conventional structure in Bangladesh. Taslima Nasrin in French Lover shows a man in a role of father, friend, lover and husband and considers women as submissive, secondary, and the 'other' thus Kannan observes that the author advocates the rejection of man as the only means of liberation of woman. Sigma G.R., in her study "Feminist Themes in Taslima Nasrin's French Lover, ” indicates selfishness of man in her sexual encounters. The protagonist and other women characters in the novel suffer sexual atrocity; Nasrin generalizes the plight of women introducing various women characters in parallel situations.

Taslima Nasreen consistently appears in newspapers and magazines, and a number of reviews on her novels are brought out from time to time. Some of the critical studies on her works are a review on French Lover like "A Search for Lilies" (2002) by Sudipta Dutta, "From Hoogly to the Seine" (2003) by Susan Chacko, and "Bold and Banned" (2004) by Sudhir Kumar. The review of Taslima Nasrin's novel -French Lover translated by Sreejata Guha, published in 2002 reveals that she raises questions against the misrule of patriarchy, its oppression, and gender bias. It examined different issues and themes related to feminism, home and homelessness, the quest for identity, cross-cultural conflict, and human 
relationships. The characters in the novel reveal tolerance, love, and harmony, where no community or sex is superior to another, and each individual has equal rights. They struggle to live with freedom and a search for the 'self' and existence. She projects her characters persistently struggling with their conflicting selves and the environment. She has also worked on various dimensions of pressures exerted by the complex nature and demands of the society in which modern man is inflicted. Her writings relate to Rogers assertion as: "the operation of inherent forces impelling each person to want to 'become' or 'realize' himself'" (qtd. in McDavid \& Harari 87).

The present study is an attempt to explore and analysis Taslima Nasrin's novel French Lover in context with existentialist philosophy and to investigate the existential perspective used by the protagonist and other characters. There is a tendency in the characters to put on efforts to take benefits of free choices and exist via their own. The present study is an attempt to explore existential perspective in the light of the characters, roles, and experience where there is the likelihood of free to choose and not to follow conventionality.

Existential philosophy emerged in the writings of Kierkegaard and Jaspers and the later contributions of Heidegger, Sartre, and others. There is no single existential philosophy; existentialism instead is more orientation towards understanding the nature and meaning of man's existence. It emphasizes that man is not a readymade machine; preferably, he has the freedom to make vital choices and to assume responsibility for his existence. It lays stress on the subjective experience as a sufficient criterion of truth. As stated by John Macquarrie and others, man exists before he acquires essence, a definite individuality. The difference is between 'being' and 'becoming.' Other things also exist, but man differs from them in that he is free to become a personality. Water or wine is simply 'being'; it cannot 'become.' Man, on the other hand, can 'become,' for instance, by choosing to deny God and traditional social values. Strong men transcend the tyrannical discipline of a dull society and create their 
values. They commit themselves to a cause in their effort to change society and can overcome life's complexities while weak men make vain efforts to escape from them.

The consciousness of the concept "“exist' that inspired the word 'existentialism,' was first articulated by Kierkegaard, and Nietzsche was among the first writers to expose the intimate relationship between experience, practice and the world that came to play a central role in existential philosophy" (Cooper 31). The single factor that goes on for existential thinkers is the freedom which is almost a synonym of existence. In the $20^{\text {th }}$ century Jean-Paul Sartre, the French philosopher adopted Kierkegaard's perspective, and for him, the human action occurs within a zone of freedom. Sartre's assertion that 'existence precedes essence' means that "man first of all exists, encounters himself, surges up in the world - and defines himself afterwards. If a man as the existentialist sees him, is not definable, it is because, to begin with, he is nothing. He will not be anything until later, and then he will be what he makes of himself" (290).

Existentialism is concerned with how individuals relate to the objective world, to other human beings and their sense of self. Recently, David Cooper argues that: “"existentialism' names a distinctive, and systematically coherent, picture of the world shared by a 'family' of thinkers" Generally, " existentialists assert the uniqueness of the human situation in the world (i.e., they reject a theoretically reductive philosophical naturalism). This situation is characterized by ambiguity and estrangement, but also by a sense of freedom and responsibility for meaning" (qtd. in Crowell 15).

Human beings are prone to a sense of estrangement or alienation from the world. Martin Buber presented alienation, as the main subject, in his book I and Thou that the person who lives in an 'I-It' relation to the world lives in "severance and alienation," without a home, a dwelling in the Universe (58). The 'I' used for 'self', conveys a meaning that is deeply personal, subjective and familiar while the 'It' is foreign and unknown, hence an alien 
presence. This estrangement is responsible for arousing the notion of existence and makes the name existentialism an appropriate one. Kierkegaard restricts the term "existence" to individual human beings where they are "infinitely interested in existing" and "constantly in the process of becoming" (253). For Macquarrie, existence means, "Man fulfils his being precisely by existing, by standing out as the unique individual that he is and stubbornly refusing to be absorbed into a system" (66). In its root sense existence means 'standing out' or going beyond what he is in that moment or moulds one's life accordingly. Kierkegaard, in his works, calls the individual to come out from the crowd and bear the burden of his being upon himself. One should not seek help from theories and principles or the illusion of conventionality because the existence of each existent is 'distinct' and 'unique' from the existence of everyone else. The other more important aspect of existence is self-relatedness -means the individual is the centre of everything, and he has to evolve his value system. It does not remain fixed or static; it keeps on changing with time.

For existentialists "we have to start from freedom if we are to understand man" (Roubiczek 122). Freedom means acting entirely by our own free will. For Sartre "freedom and existence are indistinguishable. One does not first exist and then become free; rather, to be human is already to be free" (qtd. in Macquarrie 177). Kierkegaard, Nietzsche, and Jespers call the term 'the public 'the herd' and 'mass existence' respectively that works autocratically and becomes a barrier to inhibit freedom. Existentialists believe that individuals do not get or leave a well-structured universe with a coherent design. In their dealing with freedom, people are responsible for their choices, life plans, and their world. The inescapable reality of death gives meaning to existence. It is also the source of existential or normal anxiety. Existentialists sometimes seem preoccupied with death. It is in facing death that an individual is most likely to come to an understanding of life. Frankl sees "death not as a threat but as urging for individuals to live their lives fully and to take advantage of each opportunity to do 
something meaningful" (qtd. in Sharf 176). Accordingly, death awareness can lead to creativity and living entirely rather than facing fear and dread.

Nasrin, in her writing, focuses on the inhumane practices held in the society in general, and the enslavement of woman by the patriarchal system in particular. French Lover is a novel in which she goes to the extent to break off marital and extramarital relations with the man altogether as a means of woman liberation from the subjugation of patriarchy. Nila is on a search for love and independence to discover her 'self' at abroad in a strange city far away from home. However, the quench cannot be described as satisfied but the protagonist efforts to grow in and out to overcome all situations aroused by her marital and extramarital relations.

The institution of marriage, with all its expectations, falls slowly on a woman. Nasrin is not only writing about her female protagonists Nila, who is a victim of the institution of marriage and existential crisis but through Nila, also about other women who are subjugated and enslaved. Taslima Nasrin's French Lover is the story of Nilanjana (Nila) a middle-class young Bengali girl from Kolkata who is in search of freedom, independence, and existence where she faces patriarchal control exerted on her by her father, friend, husband, and lover. She is freedom lover, energetic, and a distinctive individual who rejects whatever is crude, vulgar, and conventional. The present search focuses on the failure of premarital love where the traditions of patriarchy work as a barrier failure of marriage at which Nila gets frustration through the shabby treatment by Kishanlal, her husband and for liberation she subsequently abandons her husband.

Nila is a Bengali beauty, well educated, full of imagination with a desire to teach in a College or University. She is romantic at heart and a dreamer, wherein her first love with Sushanta, she assumes to be "a simple household" to live with minimum resources at which "they'd love each other in the dim light of the lamp in the room and laugh at the materialistic 
world outside" (13). Sushanta "a high-caste Brahmin," makes love to Nila of the lower caste but "marriage-never!" (15). Her all dreams shattered and ditches her to marry someone else. Nila marriage to Kishanlal, a non-Bengali restaurant owner, settled in Paris. She escapes the situation and moves to Paris a prosperous and secure world with several hopes and aspirations: "Nila had her share of dreams about hard life sustained only on love. Perhaps every Bengali was born with that desire" (13). Nila roams around and sees the first sight of Paris, where she takes herself fortune to her marriage with Kishan for that she became able to see the beautiful city. But further, they begin clashing with little things like his fondness for coffee and vegetarianism and hers for tea and non-vegetarianism. She is disappointed to detect that her husband is least bothered about her likes and dislikes. He never understands her freedom and autonomy. Kishan's luxurious apartment, presented in the blurb at the back of the book, appears to Nilanjana as "a gilded cage, and she feels stifled within its friendless confines. Her marriage, where she functions as little more than a housekeeper and a sex object, is far from fulfilling--and Nilanjana looks desperately for a way out of the boredom and depression that threaten to engulf her life" (Back). Nila gets suffocation for her mechanized and repetitive work schedule of a housewife. Freedom of Paris gives strength to Nila where she expresses her desire in discussion with Kishan and says: "Yes you're alive, but I don't just want to live. I need more.' 'What do you need?' Nila looked him in the eye, spoke softly and calmly, 'You're talking of bread, but that isn't all. One needs the lily as well"' (71). Kishan has failed to fulfil Nila's expectations. She gets a job of packing computers in boxes where she wants to use her potential to express her inherent urge compelling her to want to 'become' or 'realize' herself. Kishan fails to understand this natural urge for independence through earning her own money with a job.

Nila steps out of the house to explore the city streets on her own. It is her job that not merely makes money, but she also gets from it the opportunity to interact with the other 
people. Nila meets Danielle, a French citizen, who has suffered bitterly because of the sexual vulgarity of her near and dear and turned into a homosexual. Here she is free to choose and reject conventionality and exist via her way. Nila soon grows intimate with Danielle and has a friend other than Kishan. Her expansion of self begins. The conflict comes to a head when one day Nila invites her friends at home to a non-vegetarian meal cooked by her, for it Kishan was very unhappy and said: "There's no need for you to cook anymore. Now go away, get out of my sight.' Nila moved away" (78). Nila feels frustrated with Kishanlal's behaviour which makes it difficult to go with him "she finds an oppressor of woman in him, as he has never ... consider her likes and dislikes in whatever happens in the family... and Ultimately, she left Kishan and goes from work to live with her friend Danielle. Her decision to break away from the mismatched marriage has consisted of the struggle not to be swamped in the male-dominated world and to follow her inner directions to establish her own individuality. Nasrin generalizes Nila's experience as a subjugated woman and the subsequent trauma she undergoes. Her successful exit as an individual proves her to be a brave character.

Nila's mother diagnosed with cancer, and she visits India her native land with a lot of hopes. But her crises seem to be more significant when her family members and relatives behave very differently. But her mother had empowered her with a cheque of Rs. 20 lakh at her death. She is strange and feels stifled on her native land and decides to move back to France. On her back to Paris trip, Nila meets a tall' blue-eyed Frenchman Benoir Dupont, her French lover. She returns frustrated via her family, friends, and relatives from her native land to Paris. Her feeling of alienation became huge when Sunil subjugate her whom she trusts the most in the alien land. Nila faces an existential crisis that seems to occur mostly because of the control men exercise over women. A crisis in one's existence leads to a heightened sense of alienation. 
The racist nature of the French is shown when she was travelling in a local bus where two inspectors check only her ticket she was the only non-white in the bus. "The inspector's lips were twisted in a 'See, I'm never wrong. I can make out from the color who has brought a ticket and who hasn't kind of smile" (115). Sartre, an existentialist, asserts 'existence precedes essence' it means at the time of birth there is no hyphenation all individuals are equal. Rather 'in their pursuit of freedom,' individuals are responsible for their own world, their life plans, and their choices" (Sharf 176).

Benoir Dupont her French lover makes Nila aware of her body and she is lovingly touched by him. It gives her a feeling of the Prince of her dreams who has to make her life meaningful. Benoir is also curious to resolve a mystery of 'a basket of surprises.' He is eager for her blackish alien beauty with long black tresses and her large black eyes. Benoir has his family and loves his wife Pascale and daughter Jacqueline. He is clever enough when Nila falls ill he goes to Pascale telling that Jacqueline waiting for him a lot. The writer symbolizes the French lover's love with the scentless roses. Nila smelt the flowers and compare it with the Indian roses that give smell more terrific and says: "These are hybrid varieties. All the scent goes away in the process"' (271).

Nila's relationship with Benoir is instigated through her desire to overcome the feeling of insecurity. She shows off her love to everyone that she was no longer alone and lives with her French lover. Whereas, being the fact that her French lover sometimes angrily pushing him off of her bed but she cannot imagine living without him in the alien land. Gradually she accepted to be a housewife which she always denied to be. But Nila became strong as her self-confidence increases after purchasing a house of her own in Paris. Just like Kishan Benoir too needs the reassurance of her love every now and then. Benoir takes his life success when Nila gets pregnant with his child. Now he shows more love and cares towards her. But Nila finds Benoir as selfish and calculative. He loves only with himself and whatever 
he does is to please himself. Now on an alien land, social and cultural pressure loses and Nila is free from conventionality. Sexual relations also have no meaning as her chastity has violated time and again. Nila's crises go its worst when her French lover, Benoir goes to attempt her murder. At this stage, she decides to terminate her pregnancy and to be free all of the restraints. Nasrin expresses Nila's liberty as: "One, she took in deep breaths in the pure air. She stood at the window and looked out at the greens, reds, and yellow of nature, at the festival of flowers beneath the blue of the sky, the white of the clouds. Nila had never seen such pretty autumn before, had never seen nature in such gorgeous costumes" (291). In her search, in the end, she "stands alone in a strange country-penniless, friendless, and jobless. However, her instinct for survival that had always seen her through-is intact even now. She again makes plans to begin life afresh ..." (Shalini R. Sinha 184).The decision of Nila to break and go away from the patriarchal mismatched marriage and her denial to accept the life offered by the French lover, Benoir leads her to the discovery of the self where she rejects conventionality and exists authentically.

Taslima Nasrin's heroine Nila rarely submits to her contenders, she revolts against patriarchy and affirms her significance in the best possible way. She asserts herself in the matter of sexuality and economic freedom. The characters in the novel challenge the ritualistic, dogmatic, and patriarchal practices in different ways and succeed in realizing their dreams of leading a dignified, meaningful and autonomous life and existence. Nila continuously faces the anxiety of nonexistence. She feels lonely, detached and experience alienation on both native as well as on foreign land; this is due to the anxiety of nonexistence. Humans have an inherent capacity to grow and develop; they can change, make choices, and determine their own destinies. Nila assimilates herself in a new culture, on foreign land, only after leaving the older world and the nostalgia associated with it. 


\section{Works Cited}

Buber, M. I and Thou: Trans. R. Gregor Smith. Edinburgh: T. \& T. Clark, 1937. Print.

Cooper, David E. "Existentialism as a Philosophical Movement." The Cambridge Companion to Existentialism. Ed. Steven Crowell. New York: Cambridge UP, 2013. 27-49. Print.

Corbett, Bob. "What is Existentialism?” faculty. Webster.edu. Webster. edu., March 1985. N.Pag. Web. 1 May 2016.

Crowell, Steven. "Existentialism and its Legacy." The Cambridge Companion to Existentialism.Ed. Steven Crowell. New York: Cambridge UP, 2013. 3-24. Print. Kannan, P."'Rejection' of Man' in Taslima Nasrin's French lover." Feminist Psyche in World Women Novelists . Ed.N. Shantha Naik.New Delhi: Sarup and Sons, 2012. 133-162. Print.

Khatun, Saiyeda. "A Site of Subaltern Articulation: The Ecstatic Female Body in the Contemporary Bangladeshi Novels of Taslima Nasrin.” Genders 30, 1999. Web. 24 June 2015.<http://www.genders.org/g30/g30-khatun/html>.

Kierkegaard, S. Concluding Unscientific Postscript. Ed. and trans. A. Hannay. New York: Cambridge UP, 2009. Print.

Macquarrie, John. Existentialism: An Introduction, Guide and Assessment. New York: Penguin Books, 1972. Print.

McDavid, JohnW., and Herbert Harari. Psychology and Social Behaviour. New York: Harper and Row Pub., 1974. Print.

Meenakshi. "Various Manifestations of Quest for Identify in Taslima Nasrin's Writings: A Study of Lajja and French Lover.” Diss. KUK, 2010. Print.

Nasrin, Taslima. French Lover. Trans. Sreejata Guha. New Delhi: Penguin P, 2002. Print.

---. $\quad$ Lajja. Trans. Tutul Gupta. New Delhi: Penguin P, 1994. Print.

---.Phera. New Delhi: Srishti Pub. and distr., 2005. Print. 
---. $\quad$ Shodh. Trans. Rani Ray. New Delhi: Srishti Pub. and distr., 2003. Print.

Roubiczeck, Paul. Existentialism for and Against. New York: Cambridge UP, 1964. Print.

Sartre, J.P. Being and Nathiuguers. Trans. H.E. Barnes. New York: Washington Square, 1943. Print.

Sawhney, Anubha. “I Am Taslima Nasrin.” Times of India 19 Feb. 2005: n.pag. Web. 12 May 2016.

Sharf, Richards. Theories of Psychotherapy and Counselling. "Existential Therapy." Chap. 5. $2^{\text {nd }} \quad$ ed. USA: Brooks/ Cole, 2000. 166-210. Print.

Sigma, G.R. "Feminist Themes in Taslima Nasrin's French Lover." Criterion: An International Journal in English 12 (Feb. 2013). 1-4. Print.

Sinha, Shalini R. "Taslima Nasrin's French Lover- A Flawed Journey Towards SelfDiscovery." New Lights on Indian Women Novelists in English. Ed. Amar Nath Prasad. New Delhi: Sarup \& Sons, 2005. 181-86. Print.

Tiwari, A.K. "The Pen that Defies the Sword: Taslima Nasreen's All About Women."Gender Issues: Attestations and Contestations. ’Ed. Rahul Bhargava. Jaipur: Rawat Pub., 2010. 61-71. Print. 